\title{
Maturity Level of ITSM Analysis Using ITIL V3 Framework in State Electricity Enterprise Purwokerto
}

\author{
Resad Setyadi ${ }^{1}$, Enggar Priyatiningsih ${ }^{2}$ \\ ${ }^{1,2}$ Institut Teknologi Telkom Purwokerto, Indonesia \\ ${ }^{1}$ resadeittelkom-pwt.ac.id, ${ }^{2} 19103073$ dittelkom-pwt.ac.id
}

\begin{abstract}
In the industrialized world, information technology has become an essential component that everyone can feel and use. However, IT's proper use can provide opportunities for increased productivity and effective and efficient company processes. The quality of the service supplied is related to managing the problems faced and handling its day-to-day service operations. The purpose of this research is to analyze the IT service management (ITSM) of the State Electricity Enterprise (SEE) in Purwokerto with media analysis using the Information Technology Infrastructure Library (ITIL) v3 framework. The method used is a quantitative method with observation, distribution of questionnaires, and data analysis as a follow-up. Maturity level analysis becomes the target of assessment to become a reference for providing recommendations for the performance of ITSM. The results of the maturity level show that SEE Purwokerto is at the optimal level. The advice given is that SEE Purwokerto maintains IT services' performance so that the SEE Purwokerto company's business strategy continues to run well and improve.
\end{abstract}

Keywords: service operation, ITSM, state electricity enterprise, ITIL, maturity level.

\section{INTRODUCTION}

Humans need electrical resources to support all activities' fulfillment [1]. Electrical energy is essential to meet people's daily needs in their work and actions [2]. The provision of electricity for the public interest applies the principles of Limited Liability Companies [3]. Population growth and the current increase in economic activity certainly make electricity consumption increase [4]. The need for electricity is currently the primary need for the community because everyone needs it for various purposes, for example, for household activities such as lighting to businesses, both small and large levels [5]. Moreover, if there is no electricity, all-digital technology will not run [6].

The State Electricity Enterprise (SEE) is part of the Corporate Company under the Ministry of State-Owned
Enterprises (SOEs), which manages electricity procurement in Indonesia. As a company engaged in power generation and development, implementing SOEs' IT service management must [7]. SOEs use IT as a service improvement innovation, both internal and external services [8]. Besides, current IT developments can certainly provide SOEs opportunities to have service innovation to the community, manage resources appropriately and responsibly with IT risks that may be maximally handled [9]. SEE is one of the SOEs aiming to provide services in the electricity sector to the community/public utility. SEE is a company that holds electricity power in Indonesia that gives electricity needs for all Indonesians. Public services are the main focus of NEC to demonstrate efficient and effective IT service management performance in society.

Public service is an activity or a series of exercises to fulfill service needs following laws and regulations for every citizen and resident for goods, services, and administrative services provided by public service providers [10]. The relationship between public services and IT service management is very closely on SEE's IT services' maturity level to household and industrial electricity distribution. IT Service Management is IT management where IT is a service (service) that must create value for its customers. The view of IT users that providing IT services is an easy and straightforward thing, so that customer expectations of the quality of IT services are increasing. To achieve quality IT services and fulfill business needs, IT service providers continuously ensure that the IT services provided meet customer needs until they reach a Service level agreement (SLA) position. One of the standards developed regarding information technology application uses the ITIL standard [11]. This study uses the Information Technology Infrastructure Library (ITIL) framework, which provides a framework for the management and control of Information Technology services. ITIL stands for Information Technology Infrastructure Library, a framework in which there is a 
guide on how to provide Information Technology (IT) service, providers. ITIL is a series of concepts and techniques for information technology management, development, and operation. ITIL V3 has five domains: Service Strategy, Service Design, Service Transition, Service Operation, and Continual Service Improvement [12] (Fig. 1).

In this study, the authors use the Domain Service Operation. Operations Services are the operational stages of IT services that perform IT service support activities daily. The goal is to ensure that users truly feel the benefit and maintain IT services' stability through changes to increase service quality. The ten categories contained in operating services include:

\section{A. Event Management}

Monitor all events throughout the IT infrastructure, monitor normal operations and detect and escalate unwanted conditions.

\section{B. Incident Management}

Concentrate on restoring service downturns or interruptions to users as quickly as possible to minimize the business's impact.

\section{Problem Management}

Analysis to determine and resolve the cause of incidents, prevent and prevent future incidents or problems and part of the known-error process that makes diagnosis and resolution faster if further incidents occur.

\section{Request Fulfillment}

The processes for handling service requests are small and low risk, initially by going through the service desk, but using a different method similar to incident management but with another record fulfillment request related to the record of incidents or problems initiated for something requested.

\section{E. Access Management}

The process of granting authorization for users to use services to restrict access from unauthorized users.

\section{F. Service Desk}

The user's primary point of contact when the service is down, service requests, and events requested change. The service desk provides a communication point for users and a coordination point for several IT groups and processes.

\section{G. Technical Management}

Provide detailed technical capabilities and resources needed to support the sustainable operation of the IT infrastructure. Technical management also plays a role in designing, testing, releasing, and improving IT services.

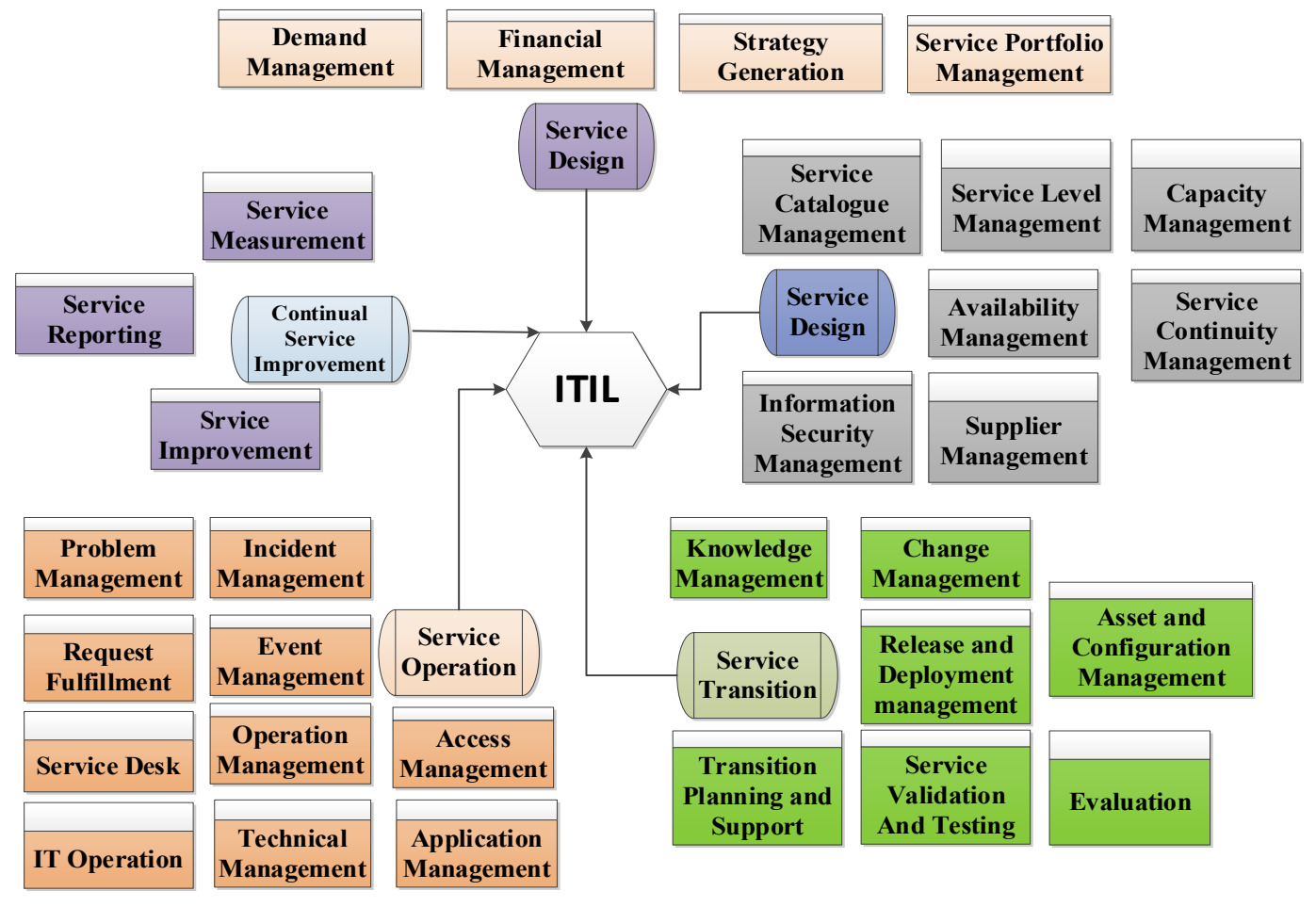

Fig. 1 ITIL V3 framework 


\section{H. IT Operation Management}

Carry out daily operational activities needed to manage IT infrastructure based on standardization during the service design stage.

\section{Application Management}

Responsible for managing applications throughout the lifecycle, supporting and managing operational applications, and playing an essential role in designing, testing, and upgrading applications that are part of IT services.

\section{$J$. Interfaces to Other Service Management Lifecycle Stages}

Some processes are executed or supported during the service operation process but are also driven by other phases in the service life cycle management.

Knowing the maturity level of information systems' use is information recommendations related to IT operational efficiency, improving service quality standards, and increasing service providers' effectiveness and efficiency [13]. The conclusion of the service maturity level for the operation service domain will be recommended for the website-based service system of the NEC Purwokerto and expected to be a reference or guideline for improving information system services.

The maturity level is a system used to measure an organization's maturity process [14] (Table I). Organizational maturity refers to the organization's ability to deliver IT services to consumers. The maturity level consists of indicators that show evidence of organizational capabilities. This evaluation assessment uses level 0 (Non-existent) - level 5 (optimized). An explanation of the scale $0-5$ is as follows [15].

1) Scale $0.00-0.83$ : Non-Existent, meaning that the company had no IT processes identified at all.

2) Scale 0.84 - 1.66: Initial; this means that the company has started to recognize the information technology process in the company, but it is not standardized yet. It is completed separately and does not have an organizational standard. There is evidence that companies are aware of resolved problems that need to be.

3) Scale 1.67-2.49: Repeatable but Intuitive; this means that the company has started using procedures in the information technology process, but there has been no formal training and communication regarding these standard procedures. This process's responsibility still rests with the individual, and the dependence on individual abilities is so high that errors will occur.
4) Scale 2.50 - 3.32: Defined Process; meaning that company procedures have been standardized, documented, and communicated through training, but how the implementation still depends on whether individuals follow the guidelines. The established procedures are not complicated, only the formalization of existing activities.

5) Scale 3.33 - 4.15: Managed and Measurable, meaning that the company can measure and monitor existing procedures so that handling is easy if a violation occurs. The current process is working fine and stable. Use limited automation and information technology tools.

6) Scale 4.16 - 5.00: Optimized; it means that the company, through continuous improvement, has achieved best practice. Information technology has been integrated and used.

From the explanation of the research background, two research questions guide the implementation of the research.

RQ1: What is IT services' maturity level in terms of the operational service domain at the SEE Purwokerto?

RQ2: What recommendations are given based on IT services' maturity level at the SEE Purwokerto?

The research method process takes steps starting from the research procedure, determining and taking data samples, data analysis, Discussion, and concluding. The analysis conducted is descriptive and inferential maturity level analysis, limitations, and research recommendations supported by other studies.

\section{METHOD}

In this study, the authors used the research method, starting from observation and distributing questionnaires and data analysis. In the observation process, the authors conducted interviews to determine the initial data using the SEE Purwokerto. Distribution of questionnaires to stakeholders, employees and consumers with a sample of 60 people from the total population that arrives in one month is 71 people.

TABLE I

MATURITY LEVEL OF ITIL FRAMEWORK

\begin{tabular}{cl}
\hline \multicolumn{1}{c}{ Index } & \multicolumn{1}{c}{ Level } \\
\hline $0.00-0.83$ & 0.- Non-Existent \\
\hline $0.84-1.66$ & 1.- Initial \\
\hline $1.67-2.49$ & 2.- Repeatable but intuitive \\
\hline $2.50-3.32$ & 3 - Defined \\
\hline $3.33-4.15$ & 4.- Managed and Measurable \\
\hline $4.16-5.00$ & 5. - Optimized \\
\hline
\end{tabular}


For the validity test, the authors used the productmoment correlation technique to test validity. The validity test helps know whether the measuring instrument measures what needs to be measured. The writer uses the product-moment method by correlating each question with the total score for each variable. Correlation figures obtained statistically must be compared with the critical statistics of the correlation table of $r$ values with a significant level of $95 \%$ (1). $r$ count $>r$ table means that the data is substantial (valid) and suitable for hypothesis testing. And vice versa if $r$ count $<$ from $r$ table indicates, the information data is not significant (invalid) and will not be included in testing the research hypothesis.

$$
r_{\text {count }}=\frac{n\left(\sum X Y\right)-\left(\sum X\right)\left(\sum Y\right)}{\sqrt{\left(n \sum X^{2}\right)-\left(\sum X\right)^{2}\left(n \sum y^{2}-\left(\sum Y\right)^{2}\right)}}
$$

$\mathrm{r}_{\text {count }}=$ correlation coefficient between $\mathrm{X}$ and $\mathrm{Y}$ variables

$\mathrm{N}=$ number of respondents

$\Sigma_{\mathrm{X}} \quad=$ total scores of the items

$\Sigma_{\mathrm{Y}} \quad=$ total scores of questions

$\Sigma_{\mathrm{X}}^{2}=$ total score squares of the items

$\Sigma_{\mathrm{Y}}^{2}=$ total score of the squares of the items

For the reliability test, the authors conducted this test to determine whether the data collection tool showed accuracy, accuracy, stability, or consistency in expressing individuals' specific symptoms, even though it did at different times. Reliability test is on statements that are already valid. This test uses the Cronbach alpha technique because the answer value consists of a range of deals with the larger alpha coefficient. Reliability means trustworthy "That is, the instrument can give the right results" (2).

$$
r_{\text {instrument }}=\left(\frac{n}{n-1}\right)\left(1-\frac{\sum s_{i}^{2}}{\sum s_{t}^{2}}\right)
$$

$$
\begin{array}{ll}
\mathrm{r}_{\text {instrument }} & =\text { reliability of instrument } \\
\mathrm{n} & =\text { number of questions } \\
\mathrm{s}_{\mathrm{i}}{ }^{2} & =\text { variance of item } \\
\mathrm{s}_{\mathrm{t}} & =\text { total variance }
\end{array}
$$

The determination of the number of samples comes from the use of the Slovin formula [16] (3).

$$
\begin{aligned}
& \mathrm{N}=\text { population } \\
& \mathrm{N}=\text { sample } \\
& \mathrm{d}^{2}=\text { significant value }=(0.05)^{2}
\end{aligned}
$$$$
\mathrm{n}=\frac{\mathrm{N}}{\mathrm{N}\left(\mathrm{d}^{2}\right)+1}
$$

The calculation of the maturity level index uses the weight value for each total sample as in the following explanation (4):

$$
\text { Index of Maturity Level }=\frac{\mathrm{wV}}{\mathrm{TS}}
$$

$$
\mathrm{WV}=\text { weight value }
$$$$
\mathrm{TS}=\text { total samples }
$$

The calculation of the maturity level average uses the total weight value for each full sub-domain times by total sample as in the following explanation (5):

$$
\text { Maturity Level Average }=\frac{\mathrm{TWV}}{\mathrm{TSD} \times \mathrm{TS}}
$$

$$
\begin{aligned}
& \text { TWV }=\text { total weight value } \\
& \text { TSD }=\text { total subdomains } \\
& \text { TS }=\text { total samples }
\end{aligned}
$$

\section{RESULTS AND DISCUSSION}

The first step in data analysis is to identify the respondent's profile. In Table II, questionnaire respondents in the SEE Purrwokerto environment have various education levels, work types, computer skills, and intensity of coming to SEE Purwokerto. Categorization of respondents aims to determine the reliability and validity of the analyzed questionnaire results [17].

TABLE II

THE RESPONDENT PROFILE

\begin{tabular}{ccc}
\hline Standard & Indicator & $\mathbf{\%}$ \\
\hline Job position & Manager of NEC & 6.7 \\
& staff of NEC & 35 \\
& private employees & 33.3 \\
& government employees & 25 \\
Education level & Diploma & 41.7 \\
& Associate degree & 13.3 \\
& Bachelor & 28.3 \\
Computer Skill & Magister & 16.7 \\
& Less & 25 \\
& Enough & 58.3 \\
Coming intensity to & Good & 16.7 \\
NEC Purwokerto & $<5$ times & 58.3 \\
\hline
\end{tabular}

\section{A. Validity Test}

The data obtained is in the validity formula for the validity test results, as shown in Table III. 
TABLE III

THE VALIDITY TEST RESULT

\begin{tabular}{cccc}
\hline Question & $\mathbf{r}_{\text {count }}$ & $\mathbf{r}_{\text {table }}$ & Result \\
\hline 1 & 0.910 & 0.571 & Valid \\
2 & 0.901 & 0.571 & Valid \\
3 & 0.902 & 0.571 & Valid \\
4 & 0.890 & 0.571 & Valid \\
5 & 0.915 & 0.571 & Valid \\
6 & 0.925 & 0.571 & Valid \\
7 & 0.905 & 0.571 & Valid \\
8 & 0.935 & 0.571 & Valid \\
9 & 0.896 & 0.571 & Valid \\
10 & 0.913 & 0.572 & Valid \\
\hline
\end{tabular}

\section{B. Reliability Test}

The Reliability test results come from research data. First, calculate the Cronbach Alpha's (CA) value using the SPSS program. The result of the calculation shows that the CA value for the reliability test is 0.963 .

\section{Maturity Test}

The maturity level test results of IT service management at SEE Purwokerto using the ITIL V3 domain of service Operation measurement tool as in Table IV.

TABLE IV

THE MATURITY LEVEL TEST RESULT

\begin{tabular}{|c|c|c|c|c|c|c|c|c|}
\hline \multirow{2}{*}{ No } & \multirow{2}{*}{ Subdomain } & \multicolumn{5}{|c|}{ Weight Value } & \multirow{2}{*}{ Value } & \multirow{2}{*}{$\begin{array}{c}\text { Maturity } \\
\text { Level }\end{array}$} \\
\hline & & 1 & 2 & 3 & 4 & 5 & & \\
\hline 1 & Event Management & 1 & 3 & 31 & 20 & 5 & 205 & 3.42 \\
\hline 2 & Incident Management & 3 & 5 & 18 & 27 & 7 & 210 & 3.50 \\
\hline 3 & Problem Management & 5 & 1 & 21 & 23 & 10 & 212 & 3.53 \\
\hline 4 & Request Fulfillment & 0 & 2 & 17 & 25 & 16 & 235 & 3.92 \\
\hline 5 & Access Management & 0 & 1 & 11 & 21 & 27 & 254 & 4.23 \\
\hline 6 & Service Desk & 8 & 2 & 18 & 15 & 17 & 211 & 3.52 \\
\hline 7 & Technical Management & 1 & 2 & 30 & 20 & 7 & 210 & 3.50 \\
\hline 8 & IT Operation Management & 0 & 1 & 16 & 21 & 22 & 244 & 4.07 \\
\hline 9 & Application Management & 0 & 2 & 11 & 24 & 23 & 248 & 4.13 \\
\hline 10 & Interfaces to Other Service Management Lifecycle Stages & 1 & 13 & 33 & 6 & 7 & 185 & 3.08 \\
\hline \multicolumn{2}{|r|}{ Total } & & & & & & 2214 & 36.9 \\
\hline \multicolumn{2}{|c|}{ Average } & & & & & & & 3.69 \\
\hline
\end{tabular}

It explains that the respondents' profile aims to show the strength of research data that is trusted, accurate, and accountable [18]. The quantitative study analysis and many methods are discussed in the literature. There is the analysis and comparing two non-probability sampling techniques for quantitative studies [19]. It needs to use the Slovin formula to determine the number of samples from the total population in one month. The use of quantitative techniques is for pay attention to ethics in research analysis so that ethical quality is also maintained [20]. However, some experts argue: quantitative research leaves out the meanings and effects of a particular system - such as a testing system is not concerned with the detailed picture of the variable [21]. The analysis of the IT service maturity level of SEE Purwokerto shows that at the level of Managed and Measurable with an average value of 3.69. It means that the SEE Purwoketo can measure and monitor existing procedures that handling is easy if a violation occurs. The current process is working fine and stable. The recommendation is to use automation tools and update several new IT / SI features in electrical services at SEE Purwokerto. SEE Purwokerto still has to optimize and improve the quality of IT services to reach the point of optimization of IT service management.

\section{CONCLUSION}

The IT Service Management Maturity Level in SEE Purwokerto has a value of 3.69 and is at level 4. The current condition of SEE is managed, and measurable, which means that IT services during the study area in a monitored and measurable state. The study recommendation is SEE Purwokerto needs to improve IT services in terms of practical data access in mobile applications and add a service desk feature to accommodate customer complaints. Suggestions for SEE Purwokerto are that the need for additional service features and IT optimization will lead to the practicality of accessing mobile applications on the SEE Purwokerto website in a portable manner, thereby increasing the effectiveness and efficiency of IT service management for SEE Purwokerto. The first suggestion for further research is that it is necessary to add a more extended study duration so that monitoring and analysis can be more accurate. The second suggestion is to use 
Continual Service Improvement from the ITIL v threedomain for IT service analysis in SEE Purwokerto.

\section{REFERENCES}

[1] V. K. M. Cheng and G. P. Hammond, "Life-cycle energy densities and land-take requirements of various power generators : A UK perspective," J. Energy Inst., vol. 90, no. 2, pp. 201-213, 2017, DOI: 10.1016/j.joei.2016.02.003.

[2] C. Sing, Y. Jia, L. Lei, Z. Xu, M. D. Mcculloch, and K. Po, "A comprehensive review on a large-scale photovoltaic system with applications of electrical energy storage," Renew. Sustain. Energy Rev., vol. 78, no. April, pp. 439-451, 2017, DOI: 10.1016/j.rser.2017.04.078.

[3] A. W. Dowling, R. Kumar, and V. M. Zavala, "A multiscale optimization framework for electricity market participation," Appl. Energy, vol. 190, pp. 147-164, 2017, DOI: 10.1016/j.apenergy.2016.12.081.

[4] B. Kahouli, "The Causality Link between Energy Electricity Consumption, $\mathrm{CO} 2$ emissions, R \& D Stocks and Economic Growth in Mediterranean Countries ( MCs ) The causality link between energy electricity consumption, $\mathrm{CO} 2$ emissions, $\mathrm{R} \& \mathrm{D}$ stocks and economic growth in," Energy, vol. 145, no. February, pp. 388-399, 2018, DOI: 10.1016/j.energy.2017.12.136.

[5] A. I. Lawal, I. Ozturk, I. O. Olanipekun, and A. J. Asaleye, "Examining the linkages between electricity consumption and economic growth in African economies Examining the linkages between electricity consumption and economic growth in African economies," Energy, vol. 208, no. July, p. 118363, 2020, DOI: 10.1016/j.energy.2020.118363.

[6] J. Morley, K. Widdicks, and M. Hazas, "Energy Research \& Social Science Digitalisation, energy and data demand: The impact of Internet traffic on overall and peak electricity consumption," Energy Res. Soc. Sci., vol. 38, no. February, pp. 128-137, 2018, DOI: 10.1016/j.erss.2018.01.018.

[7] M. Alaeddini and S. A. Hashemi, "Evaluating the Performance of IT Governance in Service-Oriented Enterprises," 2019.

[8] M. Gershman, V. Roud, and T. W. Thurner, "Open innovation in Russian state-owned enterprises," Ind. Innov., vol. 00, no. 00, pp. 1-19, 2018, DOI: 10.1080/13662716.2018.1496815.

[9] N. Jia, K. G. Huang, and C. M. Zhang, "Institutional Knowledge at Singapore Management University Public governance, corporate governance, and firm innovation : An examination of state-owned enterprises FIRM INNOVATION: AN EXAMINATION OF STATEOWNED ENTERPRISES University of Southern Califo," pp. 220-247, 2019.

[10] B. Gumah and M. A. Aziabah, " 'Our Lives Are Affected by Government Agencies': Citizens' Perception
Survey as a Measure of Public Service Efficiency in Ghana," SAGE Open, vol. 10, no. 2, 2020, DOI: 10.1177/2158244020935900.

[11] A. Omar, Z. Peñaherrera, and V. M. P. Osorio, "IT Service Management Model Based on ITIL for the Information Technology and Communications Unit of the Universidad de las Fuerzas Armadas ESPE Campus Latacunga," vol. 11, no. 6, pp. 170-175, 2020, doi: 10.18178/ijimt.2020.11.6.898.

[12] N. J. Cruz-Hinojosa and J. A. Gutiérrez-De-Mesa, "Literature review of the situation research faces in the application of ITIL in Small and Medium Enterprises," Comput. Stand. Interfaces, vol. 48, pp. 124-138, 2016, DOI: 10.1016/j.csi.2016.05.001.

[13] A. Krishna Kaiser, "Become ITIL Foundation Certified in 7 Days," became ITIL Foundation Certified in 7 Days, 2017, pp. 33-44.

[14] R. B. Dayal and R. C. Kushwaha, "Deep analysis of ITIL framework for the improvement of Indian IT services in industries," Eur. J. Mol. Clin. Med., vol. 7, no. 4, pp. 2243-2249, 2020.

[15] O. Alshathry, "Maturity Status of ITIL Incident Management Process among Saudi Arabian Organizations," Int. J. Appl. Sci. Technol., vol. 6, no. 1, pp. 40-46, 2016, [Online]. Available: http://www.ijastnet.com/journals/Vol_6_No_1_Februar y_2016/7.pdf.

[16] A. M. Adam, "Sample Size Determination in Survey Research," J. Sci. Res. Reports, vol. 26, no. 5, pp. 90-97, 2020, DOI: 10.9734/JSRR/2020/v26i530263.

[17] P. Madzík and A. Shahin, "Customer categorization using a three-dimensional loyalty matrix analogous to FMEA," Int. J. Qual. Reliab. Manag., 2020, DOI: 10.1108/IJQRM-05-2020-0179.

[18] A. Queirós, D. Faria, F. Almeida, I. Superior, and P. Gaya, "Strengths and Limitations of Qualitative and Quantitative Research Methods Innovation and Entrepreneurship View project Observatory of Portuguese Academic Spin-offs View project European Journal of Education Studies STRENGTHS AND LIMITATIONS OF QUALITATIV," pp. 369-387, 2017, DOI: 10.5281/ZENODO.887089.

[19] I. Etikan, "Sampling and Sampling Methods," Biometrics Biostat. Int. J., vol. 5, no. 6, pp. 5-7, 2017, DOI: 10.15406/BBIJ.2017.05.00149.

[20] M. J. Zyphur and D. C. Pierides, "Is Quantitative Research Ethical? Tools for Ethically Practicing, Evaluating, and Using Quantitative Research," J. Bus. Ethics, vol. 143, no. 1, pp. 1-16, 2017, DOI: 10.1007/s10551-017-3549-8.

[21] M. S. Rahman, "The Advantages and Disadvantages of Using Qualitative and Quantitative Approaches and Methods in Language' Testing and Assessment' Research: A Literature Review," J. Educ. Learn., vol. 6, no. 1, p. 102, 2016, DOI: 10.5539/JEL.v6n1p102. 